\title{
MODEL HUBUNGAN PENINGKATAN KUALITAS NILAI PERUSAHAAN MELALUI CORPORATE GOVERNANCE, GENDER DIREKTUR, REPUTASI AUDIT PADA PERBANKAN KONVENSIONAL DAN PERBANKAN SYARIAH DI INDONESIA TAHUN 2013-2018
}

\section{RELATIONSHIP MODEL FOR IMPROVING THE QUALITY OF CORPORATE VALUE THROUGH CORPORATE GOVERNANCE, GENDER DIRECTOR, AUDIT REPUTATION ON CONVENTIONAL BANKING AND SHARIA BANKING IN INDONESIA 2013-2018}

\author{
Suharti ${ }^{1}$, Anton ${ }^{2}$, Irawati ${ }^{3}$ \\ Institut Bisnis dan Teknologi Pelita Indonesia ${ }^{1,2}$ \\ Suharti.atik@,lecturer.pelitaindonesia.ac.id ${ }^{1}$,
}

\begin{abstract}
One important indicator factor for assessing the company's future prospects is to see the extent to which the company's profitability has grown. The purpose of this study was to determine the Relationship between Improving the Quality of Company Value through Corporate Governance, Gender Director, Audit Reputation in Conventional Banking and Islamic Banking in Indonesia 2013-2018. This research was conducted in listed companies that are members of the financial sector (Conventional and Sharia Banking) which are listed on the Indonesia Stock Exchange from 2013 to 2018 from 31 banking companies listed on the Indonesian stock exchange from a period of 6 years from 2013 to 2018. Methods used is purposive sampling, namely the technique of determining the sample with certain considerations. While the data analysis method using SEM and AMOS. The results of this study indicate that the Independent Board (Independent Board) does not have a significant positive effect on company performance and firm value (2) Gender Director (Female directorship) does not have a significant negative effect on company performance and firm value (3) Board Members (Managerial Board)) has a significant positive effect on company performance; but Board Members (Managerial Board) do not have a significant positive effect on firm value. (4) Audit Reputation does not have a positive significant effect on company performance and firm value.
\end{abstract}

Keywords: Audit Quality, Professional Accuracy, Competence, Ethics of Internal Auditors

\begin{abstract}
ABSTRAK
Salah satu faktor indikator penting untuk menilai prospek perusahaan dimasa datang adalah dengan melihat sejauh mana pertumbuhan profitabilitas perusahaan. Tujuan dari penelitian ini adalah untuk mengetahui Hubungan Peningkatan Kualitas Nilai Perusahaan Melalui Corporate Governance, Gender Direktur, Reputasi Audit Pada Perbankan Konvensional Dan Perbankan Syariah Di Indonesia Tahun 2013-2018. Penelitian ini dilakukan di perusahaan emiten yang tergabung pada sector keuangan (Perbankan Konvensional dan Syariah) yang terdaftar di Bursa Efek Indonesia selama 2013 sampai dengan 2018dari 31 perusahaan Perbankan yang terdaftar di bursa efek Indonesia dari rentang waktu 6 tahun dari tahun 2013 sampai tahun 2018. Metode yang
\end{abstract}


digunakan yaitu dengan purposive sampling, yakni teknik penentuan sampel dengan pertimbangan tertentu. Sedangkan metode analisis data dengan menggunakan SEM dan AMOS. Hasil penelitian ini menunjukkan bahwa Dewan Independen (Board Independen) tidak memiliki pengaruh signifikan positive terhadap kinerja perusahaan dan nilai perusahaan (2) Gender Direktur (Female directorship) tidak memiliki pengaruh signifikan negative terhadap kinerja perusahaan dan nilai perusahaan (3) Anggota Dewan (Board Manajerial) memiliki pengaruh signifikan positive terhadap kinerja perusahaan ; tapi Anggota Dewan (Board Manajerial) tidak memiliki pengaruh signifikan positive terhadap Nilai perusahaan (4) Reputasi Audit (Audit Reputation) tidak memiliki pengaruh signifikan positive terhadap kinerja perusahaan dan nilai perusahaan.

Kata Kunci : Kualitas Nilai Perusahaan, Corporate Governance, Gender Direktur ,Reputasi Audit

\section{PENDAHULUAN}

Nilai perusahaan merupakan sesuatu yang dinilai oleh suatu investor dalam melakukan Investasi. Investor akan tertarik untuk berinvestasi pada perusahaan yang harga sahamnya cenderung meningkat dari waktu ke waktu. Salah satu indicator untuk mengukur nilai perusahaan adalah Return Saham. Return merupakan suatu tingkat pengembalian kepada investor setelah berinvestasi (Jogiyanto, 2010). Bagi investor yang rasional biasanya akan melakukan analisis fundamental dan teknikal. Menurut Tandelilin (2010) salah satu faktor indikator penting untuk menilai prospek perusahaan dimasa datang adalah dengan melihat sejauh mana pertumbuhan profitabilitas perusahaan.

Selain kinerja dan nilai perusahaan, Peningkatan hutang (kewajiban) yang berlebihan tanpa pengawasan juga bisa meningkatkan risiko perusahaan. Risiko tersebut tidak diinginkan investor karena akan mempengaruhi return yang akan diperoleh. Risiko sering menjadi pemicu konflik kepentingan antara pemilik modal dengan pihak manajemen (agency problem). Problem keagenan (agency problem) antara pemegang saham (pemilik perusahaan) dengan manajer potensial terjadi bila manajemen tidak memiliki saham mayoritas. Pemegang saham tentu menginginkan manajer bekerja dengan tujuan memaksimumkan kemakmuran pemegang saham. Sebaliknya, manajer perusahaan bisa saja bertindak tidak untuk memaksimumkan kemakmuran pemegang saham tetapi memaksimumkan kemakmuran mereka sendiri. Terjadilah (conflict of interest).

Banyak Skandal terjadi karena permasalahan kepercayaan (Trust), kurangnya kepercayaan masyarakat menyebabkan peningkatan permintaan terhadap unsur tata kelola perusahaan (corporate governance) yang baik. Salah satu skandal akibat kurangnya praktik corporate governance yang menimpa negara di Amerika Serikat adalah Worldcom merupakan salah satu perusahaan terbesar di Amerika Serikat melakukan manipulasi keuangan dengan menutupi pengeluaran US\$3.8 milyar untuk mengesankan pihaknya menuai keuntungan, padahal kenyataannya rugi, Merck co \& Inc, perusahaan farmasi terbesar di Amerika Serikat melakukan mark up pendapatan sebesar US \$ 14.1 Milyar selama 3 tahun terakhir, Walt Disney Co, kesalahan pembukuan 2 tahun fiscal pada tahun fiscal 2001 UD \$ 613 juta 
atau US \$ 29 cent perlembar saham, sebelumnya dilaporkan nilainya US \$ 358 juta atau US \$ 17 cent perlembar saham. Di Indonesia sendiri banyak juga kasus yang terjadi seperti kasus Bank Century dimana banyak masyarakat yang dirugikan akibat kurangnya ketegasan dalam praktek corporate governance.

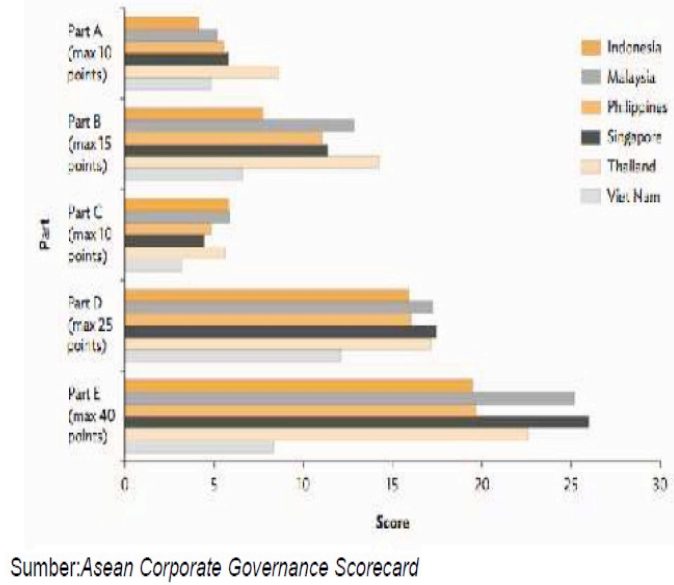

Gambar 1 Skor Perbandingan Tata Kelola Perusahaan Asean

Dari gambar tersebut juga dapat dilihat bahwa Indonesia termasuk negara yang rendah dalam mempraktekkan corporate governance dibandingkan dengan negara ASEAN lainnya.

Penelitian Juwita (2012), Kurniawan (2013) menyatakan bahwa ROE berpengaruh terhadap return saham. Semakin tinggi kinerja suatu perusahaan maka semakin tinggi minat investor dalam berinvestasi.

Menurut penelitian dari Wang (2014); Hidayat et.al, (2014) dewan komisaris memiliki hubungan yang negative dan signifikan terhadap profitabilitas sedangkan Hasil penelitian Iqbal (2010); Herdianto (2013); Rehman (2013) menunjukkan bahwa komisaris independen berpengaruh positif terhadap kinerja perusahaan.

Dalam penelitian Krishnan \& Park (2008) menunjukkan bahwa jumlah keberadaan wanita yang lebih banyak pada jajaran top manajemen yang berhubungan dengan tingkat manajemen laba yang lebih rendah. Menurut penelitian Hutchinson et al. (2015) menemukan bahwa keragaman gender pada dewan berhubungan positif dengan perusahaankinerja. Namun pada penelitian Rose (2017) tidak menemukan hubungan yang signifikan antara direktur perempuan dengan kinerja perusahaan perusahaan yang terdaftar di Denmark.

\section{METODE PENELITIAN \\ Menguji Asumsi dalam Structural Equation Modeling.}

Sebelum sampai pada hasil analisis berupa goodness of fit, perlu dilakukan pengecekan terlebih dahulu asumsi-asumsi yang melatar belakangi validitas model yang telah dibuat. Adapun asumsi dalam SEM bisadibagi menjadi dua bagian yaitu asumsi yang berkaitan dengan model dan asumsi yang berkaitan dengan praduga parameter dan pengujian hipotesis.

Asumsi-asumsi yang berkaitan dengan pendugaan parameter dan pengujian hipotesis didalam SEM (Ghozali 2017) adalah a) jumlah sampel harus besar (asymptotic), b) distribusi observe variabel multivariate normal, c) model yang dihipotesiskan harus valid, d) skala pengukuran harus kontinyu (interval).

\section{Menguji Goodness of Fit}

Pengujian model SEM adalah pengujian model overall yang melibatkan model struktural dan model pengukuran secara terintegrasi yang merupakan keseluruhan dari model. Model yang bisadikatakanbaik (fit) adalahjika model yang secara konseptual maupun teoritis didukung dengan data empirik. Uji goodness of fit 
untuk model overal $l$. menggunakan ukuran sebagai berikut :

\begin{tabular}{lc}
\multicolumn{2}{c}{ Tabel 1 Tabel Goodness Of Fit Indices } \\
\hline $\begin{array}{c}\text { Goodness of Fit } \\
\text { Index }\end{array}$ & Cut off Value \\
\hline $\begin{array}{l}\text { Chi-Square } \\
\text { Signifikan } \\
\text { Probability }\end{array}$ & Diharapkankecil , $\geq$ \\
\hline G F I & 0.05 \\
\hline A G F I & $\geq 0.90$ \\
\hline T L I & $\geq 0.90$ \\
\hline C F I & $\geq 0.90$ \\
\hline N F I & $\geq 0.90$ \\
\hline I F I & $\geq 0.90$ \\
\hline RMSEA & $\geq 0.90$ \\
\hline
\end{tabular}

Sumber : (Hair et al. 1998)

\section{Measurement Model Fit}

Langkah terakhir dari uji asumsi SEM adalah pengukuran setiap konstruk untuk menilai unidimensionalitas dan reliabilitas dari konstruk. Unidimensionalitas adalah asumsi yang melandasi perhitungan reliabilitas dan ditunjukkan ketika indicator suatu konstruk memiliki acceptable fit satu single faktor model. Pengukuran cronbach alpha tidak menjamin unidimensionalitas tetapi mengasumsikan adanya unidimensionalitas.

Pendekatan untuk menilai measurement model adalah mengukur composite reliability dan variance extracted untuk setiap konstruk. Reliability adalah ukuran internal consistency indikatorsuatu konstruk. Hasil reliability yang tinggimemberikan keyakinan bahwa indicator individu semua konsisten dengan pengukurannya. Tingkat reliability yang diterima secara umum adalah $>0.70$ sedangkan reliability $<0.70$ diterima untuk penelitian bersifat eksploratori (Ghozali, 2017).

Variance extracted merupakan ukuran validitas. Validitas adalah ukuran sampai sejauh mana semua indicator secara akurat mengukur apa yang hendak diukur. Angka yang direkomendasikan untuk variance extracted adalah $>0.50$ (Ghozali, 2017).

Rumus construct reliability dan variance extracted adalahsebagaiberikut

$$
\begin{aligned}
& \text { Construct Reliability } \\
& =\frac{\left(\sum \text { Std Loading }\right)^{2}}{\left(\sum \text { Std Loading }\right)^{2}+\sum \varepsilon j} \\
& \text { Variance Extracted } \\
& =\frac{\sum \text { Std Loading }}{\sum \text { Std Loading }}{ }^{2}+\sum \varepsilon j
\end{aligned}
$$

\section{Proses Pengolahan Data dan Uji Hipotesis}

Langkah berikutnya adalah melakukan proses pengolahan data dengan menggunakan SPSS 21 dan AMOS 21. Hasil yang diperoleh bias langsung dilakukan untuk menguji hipotesis.

\section{HASIL DAN PEMBAHASAN}

Tabel 2 Proses Pengolahan Data dan Uji Hipotesis

\begin{tabular}{lllcllc}
\hline & & & Estimate & S.E. & C.R. & P \\
\hline Y1_ROE & $<---$ & X1_BI & .051 & .031 & 1.658 & .097 \\
\hline Y1_ROE & $<---$ & X2_FD & -.014 & .038 & -.374 & .709 \\
\hline Y1_ROE & $<---$ & X3_BM & .815 & .250 & 3.262 & $.001^{*}$ \\
$* *$ \\
\hline Y1_ROE & $<---$ & X4_AR & 1.287 & 1.541 & .835 & .404 \\
\hline Y2_RS & $<---$ & X1_BI & .002 & .001 & 1.949 & $.051^{*}$ \\
\hline Y2_RS & $<---$ & X2_FD & -.001 & .001 & -.672 & .502 \\
\hline Y2_RS & $<---$ & X3_BM & .010 & .009 & 1.095 & .274 \\
\hline Y2_RS & $<---$ & X4_AR & -.042 & .053 & -.800 & .424 \\
\hline Y2_RS & $<---$ & Y1_RO & .003 & .003 & 1.002 & .316 \\
\hline
\end{tabular}

Note : $0.05^{* * *}, 0.01^{* *}, 0.1^{*}$ 


\section{Board Independence berpengaruh pada Firm Performance}

Pengujian pertama dilakukan untuk melihat pengaruh antara Board Independen terhadap Firm Performance. Berdasarkan hasil pengolahan data menggunakan Amos dikatakan signifikan apabila nilai $\mathrm{p}<0.05$ dan nilai c. $>1.96$, dari hasil output Amos didapat nilai $p$ $0.097>0.05$ dan c.r $1.658<1.96$ maka dapat disimpulkan bahwa Board Independen tidak mempunyai pengaruh signifikan terhadap Firm performance. Board independen merupakan jumlah dewan independen dalam perusahaan dimana dewan ini mewakili investor maupun pemegang saham dan tidak ada keterpihakan antara investor maupun ke perusahaan (manajer), dari hasil yang diperoleh tidak ada pengaruh dewan independen terhadap kinerja perusahaan. Hal ini dikarenakan seringnya penggantian dewan tidak independen menjadi dewan independen, yang artinya penggantian dewan terjadi pada kelompok yang sama.

\section{Female Directorship berpengaruh pada Firm Performance}

Pengujian kedua dilakukan untuk melihat pengaruh antara Female Directorship terhadap Firm Performance. Berdasarkan hasil pengolahan data menggunakan Amos dikatakan signifikan apabila nilai $\mathrm{p}<0.05$ dan nilai c.r $>1.96$, dari hasil output Amos didapat nilai $p$ $0.709>0.05$ dan c.r $0.374<1.96$ maka dapat disimpulkan bahwa Female Directorship tidak mempunyai pengaruh signifikan terhadap Firm performance. Female Directorship merupakan jumlah dewan wanita di perusahaan. Dari hasil pengolahan Amos yang diperoleh adalah female directorship tidak memiliki pengaruh terhadap kinerja perusahaan. hal ini dikarenakan sedikitnya jumlah wanita didewan dibandingkan dengan pria. Dapat juga disimpulkan bahwa gender dalam anggota dewan tidak ada pengaruhnya terhadap kinerja perusahaan yang dapat diartikan baik pria dan wanita sama-sama memiliki kemampuan untuk meningkatkan kinerja perusahaan. penelitian ini didukung oleh Rose (2017) yang juga menemukan bahwa tidak ada hubungan yang signifikan antara direktur perempuan dengan kinerja perusahaan perusahaan yang terdaftar di Denmark.

\section{Board Manajerial berpengaruh pada Firm Performance}

Pengujian ketiga dilakukan untuk melihat pengaruh antara Board Manajerial terhadap Firm Performance. Berdasarkan hasil pengolahan data menggunakan Amos dikatakan signifikan apabila nilai $\mathrm{p}<0.05$ dan nilai c.r $>1.96$, dari hasil output Amos didapat nilai p $0.001>0.05$ dan c.r $3.262>1.96$ maka dapat disimpulkan bahwa Board Manajerial mempunyai pengaruh signifikan terhadap Firm performance. Board manajerial merupakan jumlah anggota dewan diperusahaan dimana anggota dewan inilah yang mengelola dan mengendalikan perusahaan. Dari hasil pengolahan Amos didapat bahwa board manajerial memiliki pengaruh positive signifikan terhadap kinerja perusahaan. Hal ini dikarenakan semakin banyak jumlah anggota dewan maka semakin banyak yang mengelola dan mengendalikan sehingga anggota dewan dapat berkonsentrasi terhadap masalah diperusahaan dan sesama anggota dewan dapat berbagi pengalaman untuk memecahkan masalah didalam perusahaan, tentu hal ini berdampak positive terhadap perusahaan sehingga meningkatkan kinerja perusahaan. hasil penelitian ini didukung oleh penelitian Septiana et.al 
(2016), Heriyanto \& Imam (2016), menyatakan bahwa dewan direksi berpengaruh positif dan signifikan terhadap profitabilitas.

\section{Audit Reputation berpengaruh pada Firm Performance}

Pengujian keempat dilakukan untuk melihat pengaruh antara Audit Reputation terhadap Firm Performance. Berdasarkan hasil pengolahan data menggunakan Amos dikatakan signifikan apabila nilai $\mathrm{p}<0.05$ dan nilai c.r $>1.96$, dari hasil output Amos didapat nilai p $0.404>0.05$ dan c.r $0.835<1.96$ maka dapat disimpulkan bahwa Audit Reputation tidak mempunyai pengaruh signifikan terhadap Firm performance. Audit Reputation merupakan variable yang melihat KAP yang mengaudit suatu perusahaan. KAP bereputasi seperti BIG4 atau KAP yang hanya terdaftar di Indonesia saja, hal ini tentu berbeda karena KAP BIG 4 terkenal mendunia, dan memiliki banyak kantor cabang di seluruh dunia. Apabila perusahaan tidak diaudit oleh non BIG4 (hanya KAP yang terdaftar di Indonesia) hal ini tidak salah atau diperbolehkan, dan sesuai dengan peraturan di BEI. BIG4 atau tidak BIG4, hal ini berkaitan dengan reputasi KAP.

Dari hasil pengolahan Amos didapat bahwa Audit reputation tidak memiliki pengaruh yang signifikan terhadap kinerja perusahaan, hal ini dikarenakan tidak adanya peraturan yang mengharuskan perusahaan untuk diaudit oleh BIG4. Ada Sebagian perusahaan diaudit oleh KAP bereputasi juga di Indonesia, hasilnya tidak jauh berbeda dengan diaudit oleh BIG4. Tidak adanya perbedaan ini menimbulkan tidak adanya pengaruh siapa atau KAP mana yang mengaudit perusahaan. Hasil ini berbeda dengan hasil penelitian DeFond \& Lennox
(2011) yang menemukan bahwa reputasi audit memiliki dampak positive terhadap kinerja perusahaan, perusahaan yang diaudit BIG4 akan menimbulkan kepercayaan public sehingga kinerja perusahaan akan meningkat.

\section{Board Independence berpengaruh pada Firm Value}

Pengujian kelima dilakukan untuk melihat pengaruh antara Board Independence terhadap Firm Value. Berdasarkan hasil pengolahan data menggunakan Amos dikatakan signifikan apabila nilai $\mathrm{p}<0.05$ dan nilai c.r $>1.96$, dari hasil output Amos didapat nilai p $0.051>0.05$ dan c.r $1.949<1.96$ maka dapat disimpulkan bahwa Board Independence tidak mempunyai pengaruh signifikan terhadap Firm Value. Board Independen merupakan dewan independen yang dimiliki perusahaan diantara anggota dewan lainnya. Hasil pengolahan Amos menunjukkan bahwa banyak sedikitnya dewan independent di Perusahaan tidak memiliki dampak terhadap nilai perusahaan.

Hal ini dikarenakan nilai perusahaan di penelitian ini yaitu perbankan, memiliki reputasi yang baik selain melihat dewan indenpenden diperusahaan sehingga hal ini tidak memiliki dampak terhadap nilai perusahaan. Penelitian ini tidak sesuai dengan penelitian. Dari hasil penelitian ini jika menggunakan $p=0.1$ dari hasil output Amos didapat nilai $\mathrm{p}$ $0.051<0.1$ maka board independent memiliki pengaruh signifikan positive terhadap nilai perusahaan. hasil ini sesuai dengan penelitian Purnomo (2011); Purwanto (2016) menemukan bukti empiris bahwa kepemilikan manajerial berpengaruh positif terhadap return saham. 


\section{Female Directorship berpengaruh pada Firm Value}

Pengujian keenam dilakukan untuk melihat pengaruh antara Female Directorship terhadap Firm Value. Berdasarkan hasil pengolahan data menggunakan Amos dikatakan signifikan apabila nilai $\mathrm{p}<0.05$ dan nilai c.r $>1.96$, dari hasil output Amos didapat nilai p $0.502>0.05$ dan c.r $0.672<1.96$ maka dapat disimpulkan bahwa Female Directorship tidak mempunyai pengaruh signifikan terhadap Firm Value. Female directorship merupakan jumlah anggota dewan wanita yang ada di anggota dewan. Dari hasil pengolahan Amos didapat bahwa tidak terdapat hubungan antara Female directorship terhadap nilai perusahaan. Hal ini dikarenakan sedikitnya jumlah anggota dewan wanita dibandingkan pria sehingga hal ini tidak dapat diukur secara signifikan. Dari hasil ini dapat diperoleh kesimpulan bahwa tidak ada bedanya kinerja yang dilakukan oleh pria maupun wanita terhadap nilai perusahaan. Dalam penelitian ini mengambil sampel perusahaan perbankan, dimana perusahaan perbankan memiliki reputasi yang sudah baik di masyarakat.

\section{Board Manajerial berpengaruh pada Firm Value}

Pengujian ketujuh dilakukan untuk melihat pengaruh antara Board Manajerial terhadap Firm Value. Berdasarkan hasil pengolahan data menggunakan Amos dikatakan signifikan apabila nilai $\mathrm{p}<0.05$ dan nilai c.r $>1.96$, dari hasil output Amos didapat nilai p $0.274>0.05$ dan c.r $1.095<1.96$ maka dapat disimpulkan bahwa Board Manajerial tidak mempunyai pengaruh signifikan terhadap Firm Value. Board manajerial merupakan jumlah anggota dewan diperusahaan, dari hasil pengolahan Amos didapat bahwa board managerial tidak memiliki pengaruh yang signifikan terhadap nilai perusahaan. Hasil pengolahan didapat positive yang dapat diartikan semakin banyak anggota dewan maka semakin bagus nilai perusahaan, walaupun hasilnya tidak signifikan.

\section{Audit Reputation berpengaruh pada Firm Value}

Pengujian kedelapan dilakukan untuk melihat pengaruh antara Audit Reputation terhadap Firm Value. Berdasarkan hasil pengolahan data menggunakan Amos dikatakan signifikan apabila nilai $\mathrm{p}<0.05$ dan nilai c.r $>1.96$, dari hasil output Amos didapat nilai p $0.424>0.05$ dan c.r $0.8<1.96$ maka dapat disimpulkan bahwa Audit Reputation tidak mempunyai pengaruh signifikan terhadap Firm Value. Audit reputation berkaitan dengan KAP yang mengaudit suatu perusahaan. dalam penelitian ini membandingkan antara perusahaan yang diteliti oleh BIG4 dan Non Big 4. Reputasi KAP ini juga berkaitan dengan kepercayaan public terhadap perusahaan. dari hasil pengolahan Amos didapat bahwa tidak terdapat pengaruh yang significant antara Audit reputasi terhadap nilai perusahaan.

Hal ini dapat diartikan bahwa perusahaan yang diaudit BIG4 atau Non Big4 tidak ada pengaruhnya terhadap nilai perusahaan. dalam penelitian ini tidak sedikit perusahaan yang tidak melihat hal tersebut, dan memilih untuk diaudit oleh KAP yang bereputasi di Indonesia saja, dan terdaftar di BEI.

\section{Firm Performance berpengaruh pada Firm Value}

Pengujian kedelapan dilakukan untuk melihat pengaruh antara Firm Performance terhadap Firm Value. Berdasarkan hasil pengolahan data menggunakan Amos dikatakan 
signifikan apabila nilai $\mathrm{p}<0.05$ dan nilai c.r $>1.96$, dari hasil output Amos didapat nilai p $0.316>0.05$ dan c.r $1.002<1.96$ maka dapat disimpulkan bahwa Firm Performance tidak mempunyai pengaruh signifikan terhadap Firm Value. Kinerja perusahaan dalam penelitian ini adalah ROE yaitu kemampuan perusahaan untuk menghasilkan laba dari ekuitas yang dimiliki perusahaan, sedangkan nilai perusahaan dalam penelitian ini adalah return saham. Hasil pengolahan Amos menunjukkan bahwa kinerja perusahaan tidak memiliki dampak signifikan terhadap nilai perusahaan, hal ini dikarenakan kinerja perusahaan perbankan bukan dari ekuitas saja tapi ada dari dana pihak ketiga, pinjaman dan lainnya. Hasil penelitian ini tidak sesuai dengan penelitian Juwita (2012), Kurniawan, et.al (2013) menyatakan bahwa ROE berpengaruh terhadap return saham.

\section{Pengaruh Direct and Indirect Effect}

Tabel 3 Standardized Regression Weights Estimate

\begin{tabular}{llll}
\hline Y1_ROE $<---$ & X1_BI & .134 \\
\hline Y1_ROE & $<---$ & X2_FD & -.031 \\
\hline Y1_ROE & $<---$ & X3_BM & .279 \\
\hline Y1_ROE & $<---$ & X4_AR & .070 \\
\hline Y2_RS & $<---$ & X1_BI & .163 \\
\hline Y2_RS & $<---$ & X2_FD & -.057 \\
\hline Y2_RS & $<---$ & X3_BM & .100 \\
\hline Y2_RS & $<---$ & X4_AR & -.069 \\
\hline Y2_RS & $<---$ & Y1_ROE & .086
\end{tabular}

Sumber : Data olahan 2020

\section{Board Independence berpengaruh pada Firm Value Melalui Firm Performance}

Pengujian kesepuluh dilakukan untuk melihat pengaruh langsung dan tidak langsung antara Board Independence berpengaruh pada Firm Value Melalui Firm Performance. Berdasarkan hasil pengolahan data menggunakan Amos dikatakan merupakan mediasi/intervening apabila nilai langsung < $<$ nilai tidak langsung, dari hasil output Amos didapat nilai langsung dari Board Independen terhadap Firm Value adalah 0.163 dan nilai pengaruh tidak langsung adalah 0.0115 maka $0.163>0.0115$ pengaruh langsung lebih besar daripada pengaruh tidak langsung sehingga dapat disimpulkan bahwa Firm Performance bukan merupakan intervening antara Board Independence pada Firm Value. Board Independence tidak mempunyai pengaruh signifikan terhadap Firm Value melalui Firm Performance.

Hasil pengolahan Amos didapat pengaruh yang tidak signifikan positive yang dapat diartikan bahwa semakin banyak dewan independen maka semakin bagus nilai perusahaan. dari hasil ini dapat juga disimpulkan sebaiknya variable penelitian antara board independent dan nilai perusahaan dilakukan langsung tanpa intervening.

\section{Female Directorship berpengaruh pada Firm Value Melalui Firm Performance}

Pengujian kesebelas dilakukan untuk melihat pengaruh langsung dan tidak langsung antara Female Directorship berpengaruh pada Firm Value Melalui Firm Performance. Berdasarkan hasil pengolahan data menggunakan Amos dikatakan merupakan mediasi/intervening apabila nilai langsung < $<$ nilai tidak langsung, dari hasil output Amos didapat nilai 
langsung dari Female Directorship terhadap Firm Value adalah 0.057 dan nilai pengaruh tidak langsung adalah 0.00267 maka $0.057>0.00267$ pengaruh lansung lebih besar daripada pengaruh tidak langsung dapat disimpulkan bahwa Firm Performance bukan merupakan intervening antara Female Directorship pada Firm Value. Female Directorship tidak mempunyai pengaruh signifikan terhadap Firm Value melalui Firm Performance.

\section{Board Managerial berpengaruh pada Firm ValueMelaluiFirm Performance}

Pengujian kesebelas dilakukan untuk melihat pengaruh langsung dan tidak langsung antara Board Managerial berpengaruh pada Firm Value Melalui Firm Performance. Berdasarkan hasil pengolahan data menggunakan Amos dikatakan merupakan mediasi/intervening apabila nilai langsung < nilai tidak langsung, dari hasil output Amos didapat nilai langsung dari Board Managerial terhadap Firm Value adalah 0.1 dan nilai pengaruh tidak langsung adalah 0.0239 maka $0.1>0.0239$ pengaruh lansung lebih besar daripada pengaruh tidak langsung dapat disimpulkan bahwa Firm Performance bukan merupakan intervening antara Board Managerial pada Firm Value. Board Managerial tidak mempunyai pengaruh signifikan terhadap Firm Value melalui Firm Performance.

\section{Audit Reputation berpengaruh pada Firm ValueMelaluiFirm Performance}

Pengujian kesebelas dilakukan untuk melihat pengaruh langsung dan tidak langsung antara Audit Reputation berpengaruh pada Firm Value Melalui Firm Performance. Berdasarkan hasil pengolahan data menggunakan Amos dikatakan merupakan mediasi/intervening apabila nilai langsung <nilai tidak langsung, dari hasil output Amos didapat nilai langsung dari Audit Reputation terhadap Firm Value adalah 0.069 dan nilai pengaruh tidak langsung adalah 0.00602 maka $0.069>0.00602$ pengaruh lansung lebih besar daripada pengaruh tidak langsung dapat disimpulkan bahwa Firm Performance bukan merupakan intervening antara Female Directorship pada Firm Value. Audit Reputation tidak mempunyai pengaruh signifikan terhadap Firm Value melalui Firm Performance.

\section{PENUTUP \\ Kesimpulan}

Dewan Independen (Board Independen) tidak memiliki pengaruh signifikan positive terhadap kinerja perusahaan dan nilai perusahaan (2) Gender Direktur (Female directorship) tidak memiliki pengaruh signifikan negative terhadap kinerja perusahaan dan nilai perusahaan (3) Anggota Dewan (Board Manajerial) memiliki pengaruh signifikan positive terhadap kinerja perusahaan ; tapi Anggota Dewan (Board Manajerial) tidak memiliki pengaruh signifikan positive terhadap Nilai perusahaan (4) Reputasi Audit (Audit Reputation) tidak memiliki pengaruh signifikan positive terhadap kinerja perusahaan dan nilai perusahaan.

\section{Saran}

Berdasarkan hasil penelitian yang diperoleh maka dapat disarankan untuk perbaikan sebagai berikut (1) perusahaan sebaiknya memperhatikan jumlah anggota dewan diperusahaan, hal ini karena anggota dewan merupakan orang yang mengelola perusahaan, dan dari hasil penelitian didapat bahwa terdapat pengaruh terhadap kinerja perusahaan. Bagi Investor sebaiknya memperhatikan 
laporan keuangan perusahaan yaitu rasio lain sebagai bahan pertimbangan untuk investasi dan bagi peneliti lain sebaiknya penelitian dilakukan pada sector lain dengan melihat kinerja perusahaan yang lain dan disesuaikan dengan sector yang diteliti. (2) Diharapkan dengan adanya penelitian ini dapat digunakan sebagai bahan informasi dan bahan pengembangan bagi penelitian selanjutnya dengan menambah variable penelitian yang lain sehingga mendapatkan penelitian yang lebih baik

\section{Ucapan Terimakasih}

Terima kasih banyak ditujukan kepada pihak Direktorat Riset dan Pengabdian Masyarakat Direktorat Jenderal Penguatan Riset dan Pengembangan, Kementerian Riset, Teknologi, dan Pendidikan Tinggi yang telah menyediakan dana untuk penyelesaian penelitian iniSesuai Kontrak Penelitian Tahun Anggaran 2020 Nomor SP DIPA026/LL10/PG/2020, tanggal 03 Maret 2020

\section{DAFTAR PUSTAKA}

DeFond, M.,L., Lennox, C.,S., (2011). The effect of SOX on small auditor exits and audit quality. $J$. Account. Econ. (52): 21-40.

Ghozali, I., (2017). Model Persamaan Struktural, Konsep dan Aplikasi dengan Program AMOS 24, Semarang: Badan Penerbit Universitas Diponegoro.

Herdianto, F. (2013). Pengaruh Good Corporate Governance terhadap tingkat profitabilitas bank umumsyariah di Indonesia. Skripsi. Fakultas Ekonomi Universitas Negeri Malang, Malang.
Hidayat, A., W. \& Kusumastuti, R. (2014). The Influence of Corporate Governance Structure Towars Underpricing. International Journal of Administrattive Science \& Organization, 21(2).

Heriyanto, S \& Imam, M. (2016). Pengaruh Good Corporate Governance Terhadap Profitabilitas Perusahaan (Studi pada Perusahaan Manufaktur yang terdaftardi Bursa Efek Indonesia Tahun 2012-2014).

Hutchinson, M., Mack, J., Plastow, K., (2015). Who selects the 'right' directors? An examination of the association between board selection, gender diversity and outcomes. Account. Finance 55(2):1071-1103.

Iqbal, K.,S.,J.,K. (2010). Corporate Governance and its Impact on Profitability of the Pharmaceutical Industry in Pakistan. Journal of Managerial Sciences. 10(1)

Juwita, E. (2011). Analisis Economic Value Added (EVA) dan Market Value Added (MVA) sebagai Alat Pengukur Kinerja Keuangan PT SA. Jurnal Manajemen dan Organisasi, 2(2).

Jogiyanto, H. (2010). Teori Portofolio dan Analisis Investasi. Edisi ke 7. Yogyakarta : BPFEUGM.

Krishnan, H.,A. \& Park, D. (2005). A few good women-on top management teams, Journal of Business Research, 58(12):17121720.

Kurniawan, Yohanes, Jhony. (2013). Analisis pengaruh Earning Per Share (EPS), Debt to Equity Ratio(DER), Return On Assets(ROA) dan Return on Equity (ROE) terhadap Return Saham (Perusahaan Real Estate dan Property yang terdaftra di 
Bursa Efek Indonesia peridetahun 2008-2012). Jurnal Akuntansi, 03. Purnomo, A., B. (2011). Pengaruh Struktur Corporate Governance Terhadap Return Saham Pada Perusahaan Manufaktur Yang Terdaftar di BEI. Skripsi. Universitas Negeri Malang.

Purwanto, N. \& Dianawati, E. (2016). Analisis Kepemilikan Manajerial, Kepemilikan Institusional, Dewan Komite Audit, Dan Profitabilitas Terhadap Return Saham Pada Perusahaan Yang TerdaftarDalam Bursa Efek Indonesia (BEI). Jurnal Riset Mahasiswa Akuntansi. 4(2).

Rehman, A. (2013). Board Independence, Ownership Structure And Firm Performance: Evidence From Pakistan. Interdisciplinary Journal of Contemporary Research In Business. 5( 3)

Rose, C., (2017). Does female board representation influence firm performance?: The Danish evidence. Corp. Gov. Int. Rev. 15:404-413.

Septiana, N. (2016). Pengaruh Mekkanisme GCG terhadap Profiitabilitas Perusahaan. Jurnal Administrasi Bisnis (JAB) 38(2)

Tandelilin, Eduardus. (2010). Analisis Investasi dan Manajemen Portofolio. Edisi Pertama. BPFE, Yogyakarta.

Wang. Wenge. (2014). Independent Directors and Corporate Performance in China: A Metaempirical Study. International Journal of Business and Management, 2(3). 